\title{
International Study on Artemia*. XLI. Influence of culture conditions and specific diapause deactivation methods on the hatchability of Artemia cysts produced in a standard culture system
}

\author{
Patrick Lavens, Wim Tackaert \& Patrick Sorgeloos
}

Artemia Reference Center, Faculty of Agriculture, University of Ghent, Rozier 44, B-9000 Ghent, Belgium

\begin{abstract}
Using cyst material produced in an indoor cyst production system from 4 Artemia strains belonging to the species A. franciscana (San Francisco Bay, California, USA; Macau, Brasil; Great Salt Lake, Utah, USA) and A. parthenogenetica (Lavalduc, France), different factors were studied that affect dormancy in brine shrimp cysts. Preliminary experiments under varying (a)biotic culture conditions revealed an interaction between environmental conditions and hatching characteristics. Results obtained under better-defined conditions demonstrated a significant positive correlation between the amount of food available to the adult Artemia populations and the hatchability of their encysted offspring. Specific diapause deactivation treatments, e.g. hibernation of the cysts at $-25^{\circ} \mathrm{C}$ or soaking in a $3 \% \mathrm{H}_{2} \mathrm{O}_{2}$ solution, performed on one batch of Great Salt Lake cysts produced under well-defined optimal conditions, resulted in drastic increases in the hatching percentage of these cysts. Results provide indications that the variation in cyst diapause deactivation may be relevant for the stability of brine shrimp populations in their specific biotopes, e.g. inland lakes versus coastal saltworks. Possible hypotheses for differential adaptation to dormancy termination factors are discussed.
\end{abstract}

\section{INTRODUCTION}

One of the fascinating ecological adaptation mechanisms of brine shrimp Artemia " " is their ability to assure survival of the species in unstable environments by the production of dormant offspring. These encapsulated embryos can resist extreme environmental conditions, e.g. of temperature, salinity, desiccation. They remain in a state of diapause, i.e. complete

- International Interdisciplinary Study on Artemia strains, coordinated by the Artemia Reference Center, State University of Ghent, Belgium

- Species definition in the genus Artemia has become unclear, especially in view of the important genetic differences between parthenogenetic strains of brine shrimp (Abreu-Grobois \& Beardmore 1980, Abreu-Grobois 1986). It was confirmed at the First International Symposium on the Brine Shrimp Artemia that, unless the exact sibling species can be identified, and until speciation in brine shrimp is better understood, only the genus designation Artemia should be used (Persoone et al. 1980) arrest of metabolism, initiated by internal factors before the environment turns unfavorable, until a deactivation process allows the embryo to resume its metabolism and further embryonic development when submitted to optimal hatching conditions. The exact biochemical mechanisms involved in this diapause process are not yet fully understood (Clegg \& Conte 1980)

Although dehydration is probably one of the most effective treatments in terminating dormancy, it appears from the literature on this subject (see summary in Table 1 ; see review by Lavens \& Sorgeloos 1986 a) that several other treatments can also be effective, e.g. pre-incubation at low temperatures or decapsulation have been reported to initiate quiescence in resting eggs from various crustaceans and rotifers. However, the literature on diapause inhibition is often very confusing and even contradictory. This is mainly because the experimental cyst material was not standardized, i.e. details about its origin were not known, 
Table 1. Effect of different diapause inhibition methods on resting eggs of different crustacean and rotifer taxa (compiled from Lavens \& Sorgeloos 1986a). Presence of a spot indicates a diapause terminating effect for the technique applied

\begin{tabular}{|c|c|c|c|c|c|c|c|}
\hline \multirow{2}{*}{$\begin{array}{l}\text { Diapause deactivation } \\
\text { technique }\end{array}$} & \multicolumn{6}{|c|}{ Crustacea } & \multirow{2}{*}{$\begin{array}{l}\text { Rotifera } \\
\text { Monogo- } \\
\text { nonta }\end{array}$} \\
\hline & $\begin{array}{c}\text { Anostraca } \\
\text { (Artemia spp.) }\end{array}$ & $\begin{array}{c}\text { Anostraca } \\
\text { (non Artemia) }\end{array}$ & $\begin{array}{l}\text { Noto- } \\
\text { straca }\end{array}$ & $\begin{array}{l}\text { Concho- } \\
\text { straca }\end{array}$ & $\begin{array}{l}\text { Clado- } \\
\text { cera }\end{array}$ & $\begin{array}{l}\text { Cala- } \\
\text { noidea }\end{array}$ & \\
\hline Dehydration & $\bullet$ & - & $\bullet$ & - & & & $\bullet$ \\
\hline $\begin{array}{l}\text { Repeated dehydration/ } \\
\text { hydration cycles }\end{array}$ & & & - & & & & \\
\hline $\begin{array}{l}\text { Pre-incubation at } \\
\text { low temperatures }\end{array}$ & - & - & - & & & - & - \\
\hline Ilumination & $\bullet$ & & - & $\bullet$ & $\bullet$ & $\bullet$ & $\bullet$ \\
\hline U. V. irradiation & - & & $\bullet$ & & & & \\
\hline Cosmic radiation & - & & & & & & \\
\hline Magnetic fields & - & & & & & & \\
\hline Osmotic shock & & - & & & & & \\
\hline Organic solvents & $\bullet$ & - & & & & & \\
\hline Peroxide treatment & $\bullet$ & & & & & & \\
\hline Decapsulation & $\bullet$ & & $\bullet$ & & $\bullet$ & & \\
\hline $\begin{array}{l}\text { Manipulation of } \\
\text { internal } \mathrm{pH}\end{array}$ & $\bullet$ & & & & & & \\
\hline Anaerobiosis & & $\bullet$ & $\bullet$ & & & & \\
\hline Water depth & & $\bullet$ & & & & & \\
\hline Freshwater & & - & & & & & \\
\hline
\end{tabular}

such as time of deposition of the dormant gastrulae, environmental conditions under which they were produced, and possible exposures to dehydration-hydration cycles. As a result the study material used could already have been deactivated, thus remaining in a state of quiescence with an environmental, and no longer an endogenous, control of their metabolism and development. In this way possible effects of specific diapause deactivation techniques could have been masked.

For this study standard cyst material has been produced in a cyst production system that allows maximal control of the abiotic and biotic culture conditions. Moreover, the offspring can be harvested within $24 \mathrm{~h}$ after deposition. Different culture conditions and diapause inhibition techniques have been tested for their influence on the hatchability of the cysts.

\section{MATERLALS AND METHODS}

Details on the geographical origin and the batch identification of the 4 Artemia strains used in this study as inoculum for the standard cyst production runs are given in Table 2. Details on the controlled cyst production unit and on the culture conditions are outlined in Lavens \& Sorgeloos (1984). The following parameters were kept constant unless otherwise indicated.

Animal density: approximately 5,000 Artemia adults $1^{-1}$; total number of individuals used per experiment was 250000 .

Artificial seawater: (Lavens et al. 1985); $25^{\circ} \mathrm{C}$; 90 ppt.

Food: in the first set of experiments different mono- or mixed diets were used, consisting of spray-dried Spirulina (SPIR), a byproduct of rice starch extraction (ARP), and micronised waste products from agricultural crops e.g. rice bran (RB), corn (YMOO and UNICA). A mixture of RB and YMOO was used in the other culture tests.

Artemia strain: only 3 strains (Lavalduc, Macau, and Great Salt Lake) were used in the first experiment; Lavalduc and San Francisco Bay material was tested for evaluating the influence of food quantity given to the parental animals on the hatching characteristics of the produced cysts; in the third experiment only Great Salt Lake Artemia was used.

Upon harvest the cysts produced were stored in brine and eventually processed following the procedure of Sorgeloos et al. (1985). Repeated hydration-dehydration cycles were carried out by internupting the normal hatching process after $3 \mathrm{~h}$ incubation followed by transfer of the cysts for $24 \mathrm{~h}$ to saturated brine. The

Table 2. Artemia strains and batches used as inoculum for the lab culture experiments

\begin{tabular}{|lcc|}
\hline \multicolumn{1}{|c|}{ Source of cysts } & Abbreviation & $\begin{array}{c}\text { Batch number } \\
\text { or year of harvest }\end{array}$ \\
\hline $\begin{array}{l}\text { A. franciscana } \\
\text { San Francisco Bay, USA }\end{array}$ & SFB & No. 2596 \\
$\begin{array}{l}\text { Great Salt Lake, USA } \\
\text { Macau, Brazil }\end{array}$ & GSL & $\begin{array}{c}\text { No. } 185.0 \\
1979\end{array}$ \\
$\begin{array}{l}\text { A. parthenogenetica } \\
\text { Lavalduc, France }\end{array}$ & LVD & 1979 \\
\hline
\end{tabular}


peroxide treatment consisted of soaking the processed, dehydrated cysts in a $3 \% \mathrm{H}_{2} \mathrm{O}_{2}$ solution in the same way as for standard hatching (Vanhaecke \& Sorgeloos 1982). After the required period, cysts were collected on a sieve, rinsed with tap water, and incubated again in seawater.

Hatching percentages were determined according to the procedure outlined in Bruggeman et al. (1980). The tests of different diapause deactivation techniques on the hatchability were designed to enable statistical interpretation by means of a 1-way analysis of variance, Model I (Sokal \& Rohlf 1969). The hatching data were normalised through an arc sin $\sqrt{\text { percent }}$ transformation. The test of Duncan was used to calculate significant differences.

\section{RESULTS}

The first batches of cysts, originating from 3 Artemia strains and produced in the controlled cyst production system, revealed very important differences in hatch-

Table 3. Artemia spp. Hatching percentages for cysts produced in a standard laboratory culture system. (Explanations of abbreviations are given in Table 2 and in Materials and Methods')

\begin{tabular}{|c|c|c|c|}
\hline Strain & $\begin{array}{l}\text { Culture } \\
\text { conditions }\end{array}$ & $\begin{array}{l}\text { Hatching } \\
\text { percentage }\end{array}$ & $\mathrm{SD}$ \\
\hline LVD & $\begin{array}{c}50 \mathrm{ppt} \\
10,000 \text { ind } \mathrm{I}^{-1} \\
\mathrm{RB}\end{array}$ & 5.0 & 2.6 \\
\hline LVD & $\begin{array}{c}50 \mathrm{ppt} \\
10,000 \text { ind } \mathrm{l}^{-1} \\
\mathrm{RB}\end{array}$ & 20.8 & 1.9 \\
\hline LVD & $\begin{array}{c}50 \mathrm{ppt} \\
10,000 \text { ind } \mathrm{I}^{-1} \\
\mathrm{RB} / \mathrm{SPIR}\end{array}$ & 31.0 & 14.0 \\
\hline MAC & $\begin{array}{l}90 \mathrm{ppt} \\
3,000 \text { ind } 1^{-1} \\
\text { UNICA }\end{array}$ & 35.1 & 4.5 \\
\hline MAC & $\begin{array}{c}90 \mathrm{ppt} \\
3,000 \text { ind } \mathrm{I}^{-1} \\
\text { UNICA/SPIR }\end{array}$ & 71.1 & 7.9 \\
\hline GSL & $\begin{array}{c}50 \mathrm{ppt} \\
10,000 \text { ind } \mathrm{l}^{-1} \\
\mathrm{RB}\end{array}$ & 3.9 & 3.8 \\
\hline GSL & $\begin{array}{l}\quad 90 \mathrm{ppt} \\
5,000 \text { ind } \mathrm{I}^{-1} \\
\text { RB/YMOO }\end{array}$ & 1.0 & - \\
\hline GSL & $\begin{array}{c}35 \mathrm{ppt} \\
5,000 \text { ind } \mathrm{l}^{-1} \\
\text { ARP }\end{array}$ & 46.3 & 5.0 \\
\hline
\end{tabular}

ing percentages (see data in Table 3). Although analogous culture conditions were applied, hatchability of Lavalduc offspring varied significantly from 5 to $21 \%$; an extra $10 \%$ increase was noted when Spirulina was added to the diet; a similar effect was observed with Macau Artemia for which hatching percentages even doubled (from 35 to $71 \%$ ). These results indicate that the culture conditions under which the cysts were produced were not yet fully standardized as was previously accepted, and thus that other, neglected parameters were still interfering. This is further confirmed by the varying hatching results (1 to $46 \%$ ) of the cysts from Great Salt Lake, which were produced under varying culture conditions (food quality and salinity).

In an attempt to improve control of the culture parameters, more attention was paid to the feeding conditions in the second set of experiments. The results of these tests revealed an obvious interaction between the amount of food available to the parental cultures and the hatching characteristics of the cysts produced (see hatching results for a parthenogenetic and a zygogenetic strain in Fig. 1). Cyst hatchability increased significantly $(p<0.05)$ when the adults received more food, i.e. optimal levels versus suboptimal food quantities. The effect was even more

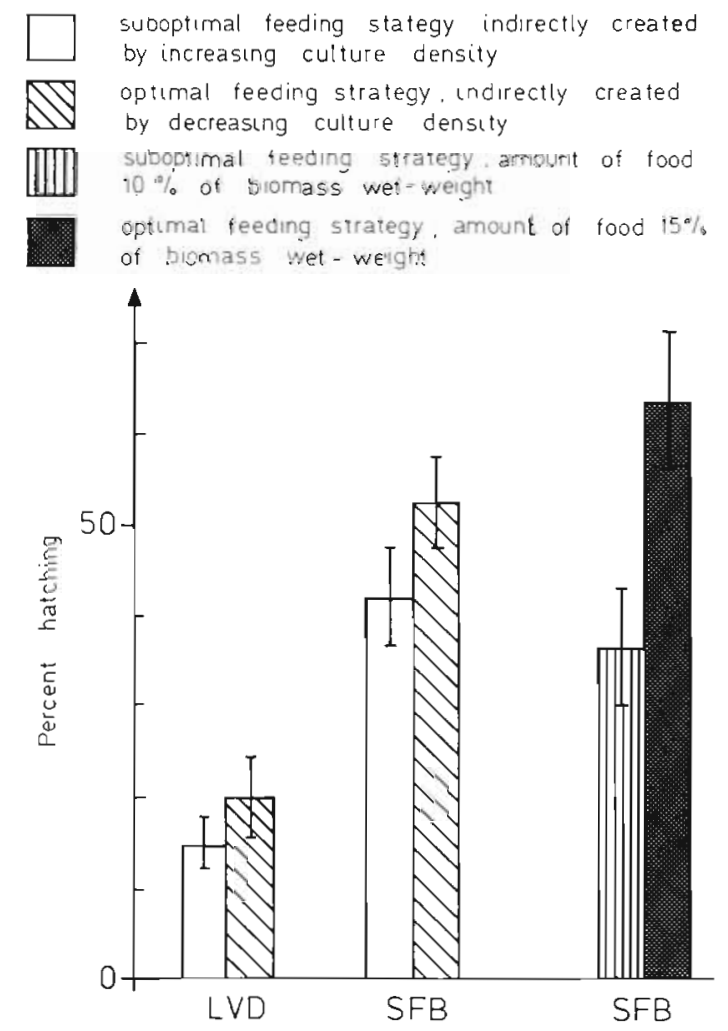

Fig. 1. Artemia. Hatchability $(\%)$ of lab-produced cysts in relation to the feed quantity available to parental cultures. Standard deviations of mean given by error bars 
pronounced for the cysts produced in the tests where varying amounts of food were given.

Nonetheless, best hatching results obtained with cysts from these laboratory cultures were still not comparable to the higher yields obtained with cysts from commercial sources $(75$ and $80 \%$ respectively for Lavalduc and San Francisco Bay: Vanhaecke \& Sorgeloos 1983).

Specific diapause deactivation treatments were performed with cysts from the Great Salt Lake strain. From Table 4 it appears that prolonged hibernation or pretreatment of the cysts in a peroxide solution have a drastic effect on the hatchability of the cysts. Minor effects were noted for the U.V. irradiation treatment. On the other hand different dehydration techniques, e.g. storage in $\mathrm{NaCl}$ or $\mathrm{MgCl}_{2}$ and oven drying, or hydration-dehydration cycles, did not result in significant increases in hatchability (Fig. 2).

\section{DISCUSSION}

The poor hatchability of some commercial batches of Artemia cysts has often been blamed on improper processing of the cysts after collection in nature (Van-

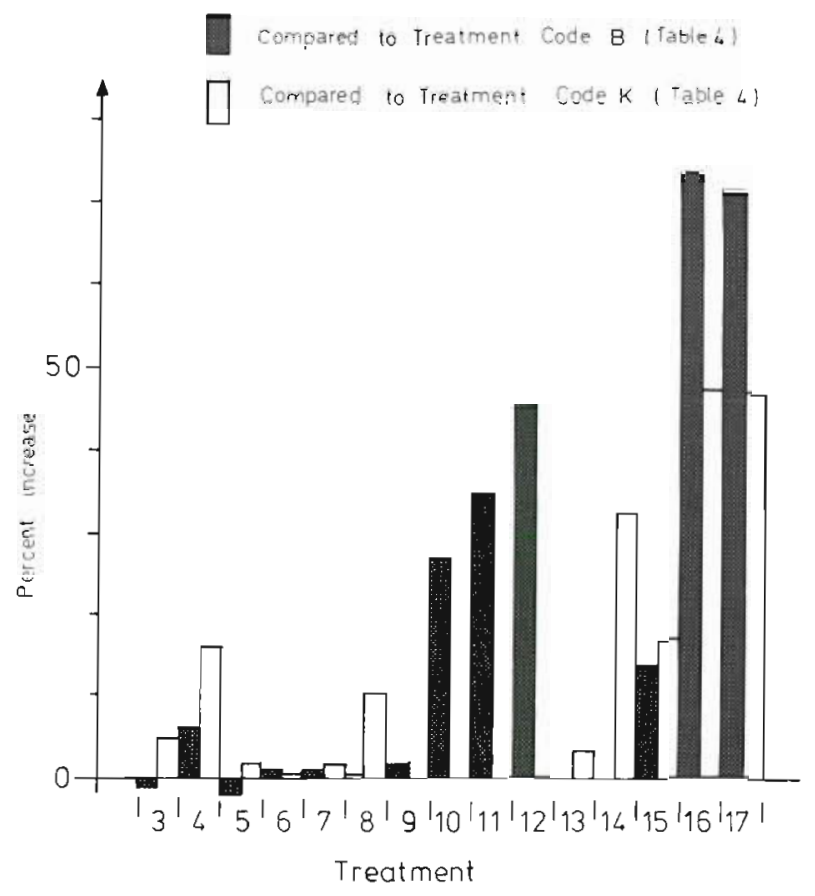

Fig. 2. Artemia. Increase in hatchability of lab-produced GSL cysts by specific diapause deactivation methods. See Table 4 for explanation of treatment numbers

Table 4. Artemia. Effect of different diapause deactivation treatments on the hatchability of Great Salt Lake cysts produced under laboratory conditions

\begin{tabular}{|c|c|c|c|c|c|c|c|}
\hline \multirow[t]{2}{*}{$\begin{array}{c}\text { Diapause inhibition } \\
\text { treatments }\end{array}$} & \multirow[t]{2}{*}{$\begin{array}{l}\text { Treatment } \\
\text { number }\end{array}$} & \multicolumn{2}{|c|}{$\begin{array}{c}\text { Processed cysts } \\
\text { hatching }\end{array}$} & \multirow[t]{2}{*}{$\begin{array}{l}\text { Treatment } \\
\text { code }\end{array}$} & \multicolumn{2}{|c|}{$\begin{array}{c}\text { Hibernated cysts } \\
\left(2 \times 4 \text { wk at }-25^{\circ} \mathrm{C}\right) \\
\text { hatching }\end{array}$} & \multirow[t]{2}{*}{$\begin{array}{l}\text { Treatment } \\
\text { code }\end{array}$} \\
\hline & & $\%$ & $\mathrm{SD}$ & & $\%$ & $\mathrm{SD}$ & \\
\hline \multicolumn{8}{|c|}{ Storage at ambient temperature } \\
\hline $1 \mathrm{mo}$ & 1 & 0.6 & 0.7 & A & 38.5 & 4.2 & $\mathrm{~K}$ \\
\hline $3 \mathrm{mo}$ & 2 & 3.7 & 1.5 & $\mathrm{~B}$ & - & - & \\
\hline Dehydration in $\mathrm{MgCl}_{2}$ & 3 & 2.7 & 0.9 & $\mathrm{C}$ & 43.3 & 3.4 & $\mathrm{P}$ \\
\hline Drying: 24 h at $35^{\circ} \mathrm{C}$ & 4 & 11.0 & 2.4 & $\mathrm{D}$ & 55.4 & 7.2 & $Q$ \\
\hline \multicolumn{8}{|l|}{ Hydration/dehydration } \\
\hline 1 cycle & 5 & 1.7 & 0.9 & $E$ & 40.6 & 6.9 & $\mathrm{R}$ \\
\hline 2 cycles & 6 & 4.8 & 1.9 & $\mathrm{~F}$ & 39.1 & 5.1 & $\mathrm{~S}$ \\
\hline 3 cycles & 7 & 4.7 & 1.5 & $\mathrm{G}$ & 40.1 & 5.5 & $T$ \\
\hline U. V.: $6 \mathrm{~h} / 30 \mathrm{~W}$ & 8 & 4.2 & 1.1 & $\mathrm{H}$ & 48.9 & 3.7 & $\mathrm{U}$ \\
\hline \multicolumn{8}{|l|}{ Hibernation } \\
\hline $8 w \mathrm{k}$ at $\quad 4^{\circ} \mathrm{C}$ & 9 & 5.6 & 1.7 & I & - & - & \\
\hline 4 wk at $-25^{\circ} \mathrm{C}$ & 10 & 30.9 & 3.7 & $\mathrm{~J}$ & - & - & \\
\hline $2 \times 4 w k$ at $-25^{\circ} \mathrm{C}$ & 11 & 38.5 & 4.2 & $\mathrm{~K}$ & - & - & \\
\hline $8 w \mathrm{k}$ at $-25^{\circ} \mathrm{C}$ & 12 & 49.1 & 3.8 & $\mathrm{~L}$ & - & - & \\
\hline $12 w k$ at $-25^{\circ} \mathrm{C}$ & 13 & - & - & & 42.1 & 6.1 & V \\
\hline 24 wk at $-25^{\circ} \mathrm{C}$ & 14 & - & - & & 71.1 & 6.3 & $w$ \\
\hline \multicolumn{8}{|l|}{ Peroxide } \\
\hline $10 \mathrm{~min} / 3 \% \mathrm{H}_{2} \mathrm{O}_{2}$ & 15 & 18.0 & 2.8 & M & 56.4 & 4.8 & $x$ \\
\hline $30 \mathrm{~min} / 3 \% \mathrm{H}_{2} \mathrm{O}_{2}$ & 16 & 77.4 & 6.9 & $N$ & 85.6 & 8.9 & Y \\
\hline $60 \mathrm{~min} / 3 \% \mathrm{H}_{2} \mathrm{O}_{2}$ & 17 & 74.8 & 3.3 & 0 & 85.0 & 4.1 & $\mathrm{Z}$ \\
\hline
\end{tabular}


Table 5. Variance analyses and Duncan tests on data presented in Table 4. Underlined letters indicate no significant. difference at the 0.05 level

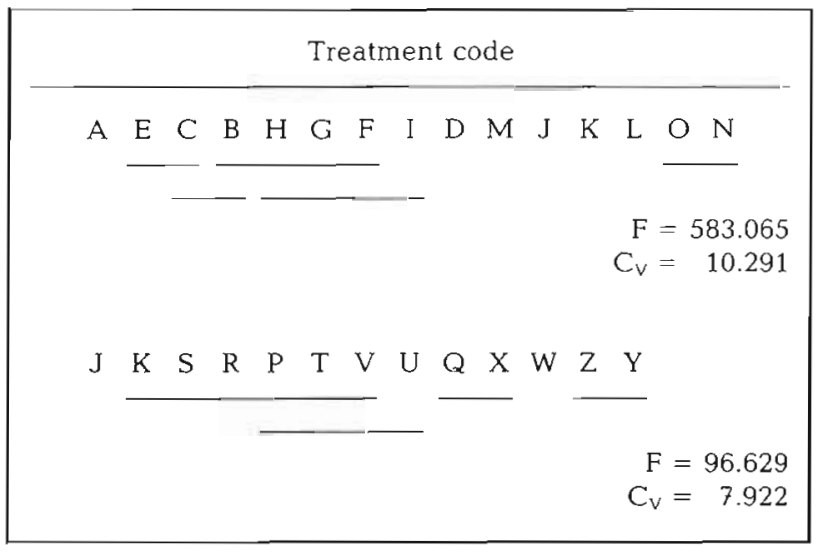

haecke \& Sorgeloos 1982). The results presented in this paper, however, clearly demonstrate that the culture conditions under which the cysts are produced, as well as specific diapause deactivation techniques, can significantly influence the hatching characteristics of dormant eggs. This may also explain the confusion existing in the literature since either of these parameters may have masked the effects of experimental conditions.

Food availability to the parents appears to be the factor of primary importance in determining the hatching quality of the cysts produced. The great variation in hatching percentages of the cysts produced in the first set of experiments might also be explained by suboptimal feeding levels; in fact it was only in the second set of tests that maximal (i.e. optimal) feeding levels of $15 \%$ of population wet weight biomass $\mathrm{d}^{-1}$ (Lavens \& Sorgeloos 1986b) were applied. This correlation between food quantity and hatchability of Artemia cysts has recently been confirmed by Tackaert et al. (1986) using Dunaliella spp. as a food source for heritability studies in batch culture systems with different Artemia strains.

The interaction between food availability in adult cultures and the hatchability of their encysted, dormant eggs is unclear. It may interfere with either the state of dormancy itself, e.g. resulting in a variable sensitivity for diapause deactivation treatments, or it may affect the embryogenesis of the cysts, e.g. by changing the carbohydrate levels which are critical for an optimal functioning of the trehalose-glycerol hyperosmotic regulatory system (Conte et al. 1977). Preliminary analyses of sugar content of laboratoryproduced cysts revealed no correlation between trehalose or glycerol concentrations in the cysts and their hatchability or parental food availability (Lavens unpubl.).
This study also provides evidence that specific diapause deactivation methods may affect the hatchability of freshly released cysts, at least in some strains of Artemia. Pre-incubation at low temperatures $\left(-25^{\circ} \mathrm{C}\right)$ for extended periods and treatment with a $3 \%$ peroxide solution for a maximum of $1 \mathrm{~h}$ act as especially efficient dormancy terminating methods. The combination of both diapause deactivation methods yielded cysts of Great Salt Lake Artemia with a hatching quality as high as $86 \%$, which is higher than the best figure of $75 \%$ obtained in cysts collected from the Great Salt Lake biotope (Vanhaecke \& Sorgeloos 1983).

The data presented here also reveal that hibernation is a quantitative effect, i.e. a function of incubation period and temperature. Analogous effects at $4{ }^{\circ} \mathrm{C}$ were reported for brine shrimp cysts from the Azov sea (USSR) saltworks (Voronov 1973) and from Mono Lake, California, USA (Dana 1981, Thun \& Starrett 1986). In Lake Lavalduc (France) Artemia, maximal hatchability is ensured after $14 \mathrm{~d}$ storage of the dormant embryos at $-25^{\circ} \mathrm{C}$ (Sorgeloos 1979, Godeluck 1980). Since the latter Artemia strains all occur in temperate regions, it is very likely that they display hibernation as an excellent adaptation to the local environment, i.e. not only can encysted offspring produced during summer be saved from unfavourable conditions in winter but, furthermore, this hibernation effect will ensure that in spring all cysts are quiescent, resulting in synchronous hatching and fast start-up of the new population. A similar adaptation has been reported by Marcus (1979, 1980) for the calanoid copepod Labidocera aestiva.

Differences between Artemia strains in diapause deactivation sensitivity might be related to variations in habitat conditions. This might explain why dehydration or dehydration-hydration cycles do not affect Great Salt Lake cysts but do deactivate diapause in (sub)-tropical populations. Although still a hypothesis, such climatic adaptations might have resulted in long term adaptations and even in strain-specific differences among Artemia belonging to the same sibling species but living in widely different habitats, e.g. A. franciscana from San Francisco Bay and Great Salt Lake. In fact, this should not be surprising in Artemia since this differential adaptation of geographically separated populations has been well documented in various other invertebrates (see review by Lavens \& Sorgeloos 1986a).

The peroxide treatment is very effective and totally suppresses the need for hibernation. Its effect on brine shrimp hatching was reported by Bogatova \& Schmakova (1980) who claimed that the reactive oxygen atoms catalyse the oxidation-reduction process whereby trehalose is converted into glycerol and glycogen during embryogenesis (Muramatsu 1960, Emer- 
son 1963). In this regard the observation of Van Der Linden (pers, comm.) that the light triggering effect in hydrated Artemia cysts (Sorgeloos 1973) decreases in cysts that have been pre-incubated in peroxide might be of interest, especially since this illumination energy normally serves to catalyse oxidation-reduction processes via captation by haem pigments (Van Der Linden et al. 1986).

In conclusion, our findings confirm the urgent need for standardized cyst material of well-known production origin. This is essential for the further study of the basic mechanisms involved in the diapause deactivation and consequently the hatching metabolism in Artemia cysts. This research might not only result in a better understanding of the specific ecological adaptations of this organism to its environment but, moreover, will contribute to a more economical use of this precious live food in aquaculture.

Acknowledgements. This study has been made possible through the Belgian National Science Foundation (NFWO) grant FKFO 32.0012.82, the Institute for the Promotion of Industry and Agriculture (IWONL), the N.V. Artemia Systems and the Environmental Protection Agency (EPA) grant CR 811042-02-0. P.S. is a senior scientist with the NFWO.

\section{LITERATURE CITED}

Abreu-Grobois, A. (1986). Review on the genetics of the genus Artemia. In: Sorgeloos, P., Bengtson, D. A., Decleir, W. (ed.) Proceedings Second International Symposium on the brine shrimp Artemia. Universa Press, Wetteren, Belgium. (In press)

Abreu-Grobois, F. A., Beardmore, J. A. (1980). International study on Artemia. II. Genetic characterization of Artemia populations - an electrophoretic approach. In: Persoone, G., Sorgeloos, P., Roels, O. A., Jaspers, E. (ed.) The brine shrimp Artemia. Vol. 1. Morphology, genetics, radiobiology, toxicology. Universa Press, Wetteren, Belgium, p $133-146$

Bogatova, I. B., Schmakova, Z. I. (1980). Activation of diapausing eggs of Artemia salina. Gidrobiol. Zh. 16 (3): 108-110

Bruggeman, E., Sorgeloos, P., Vanhaecke, P. (1980). Improvements in the decapsulation technique of Artemia cysts. In: Persoone, G., Sorgeloos, P., Roels, O. A., Jaspers, E. (ed.) The brine shrimp Artemia. Vol. 3. Ecology, culturing, use in aquaculture. Universa Press, Wetteren, Belgium, p. $261-269$

Clegg, J. S., Conte, F. P. (1980). A review of the cellular and developmental biology of Artemia. In: Persoone, G., Sorgeloos, P., Roels, O. A., Jaspers, E. (ed.) The brine shrimp Artemia. Vol. 2. Physiology, biochemistry, molecular biology. Universa Press, Wetteren, Belgium, p. 11-54

Conte, F. P., Droukas, P. C., Ewing, R. D. (1977). Development of sodium regulation and de novo synthesis of $\mathrm{Na}+\mathrm{K}$ activated ATPase in larval brine shrimp Artemia salina. J. exp. Zool. 202 (3): 339-361

Dana, G. L. (1981). Comparative population ecology of the brine shrimp Artemia. M. Sc thesis, San Francisco State University

Emerson, D. N. (1963). The metabolism of hatching embryos of the brine shrimp Artemia salina. Proc. S. Dak. Acad. Sci 42: $131-135$

Godeluck, B. (1980). Etude comparée des récoltes et traitements des oeufs d'Artemia salina des salines du Midi en provenance de l'étang de Lavalduc. Ph. D. thesis, Université Pierre et Marie Curie, Paris

Lavens, P., Baert, P., De Meulemeester, A., Van Ballaer, E. Sorgeloos, P. (1985). New developments in the high density flow-through culturing of brine shrimp Artemia. J. World Maricul. Soc. 16: in press

Lavens, P., Sorgeloos, P. (1984). Contralled production of Artemia cysts under standard conditions in a recirculating culture system. Aquacultural Eng. 3: 221-235

Lavens, P., Sorgeloos, P. (1986a). Review of the cryptobiotic state of Artemia cysts and its diapause deactivation. In: Sorgeloos, P., Bengtson, D. A., Decleir, W. (ed.) Proceedings Second International Symposium on the brine shrimp Artemia. Universa Press, Wetteren, Belgium. (In press)

Lavens, P., Sorgeloos, P. (1986b). Design, operation, and potential of a culture system for the continuous production of Artemia nauplii. In: Sorgeloos, P., Bengtson, D. A., Decleir, W. (ed.) Proceedings Second International Symposium on the brine shrimp Artemia. Universa Press, Wetteren, Belgium. (In press)

Marcus, N. H. (1979). On the population biology and nature of diapause of Labidocera aestiva (Copepoda: Calanoida). Biol. Bull. mar. biol. Lab., Woods Hole 157: 297-305

Marcus, N. H. (1980). Photoperiodic control of diapause in the marine calanoid copepod Labidocera aestiva. Biol. Bull. mar. biol. Lab., Woods Hole 159 (2): 311-319

Muramatsu, S. (1960). Studies on the physiology of Artemia embryos I. Respiration and its main substrate during the early development of the encysted embryo. Embryologia 5 (1): 95-106

Persoone, G., Sorgeloos, P., Roels, O., Jaspers, E. (ed.) (1980). Editoral note on Artemia taxonomy. In: The brine shrimp Artemia. Vol. 1, Morphology, genetics, radiobiology, toxicology; Vol. 2, Physiology, biochemistry, molecular biology; Vol. 3, Ecology, culturing, use in aquaculture. Universa Press, Wetteren, Belgium, p. XVII

Sokal, R. R., Rohlf, F. J. (1969). Biometry. W H. Freeman and Co., San Francisco

Sorgeloos, P. (1973). First report on the triggering effect of light on the hatching mechanism of Artemia salina dry cysts. Mar. Biol. 22: 75-76

Sorgeloos, P. (1979). Het gebruik van het pekelkreeftje Artemia spec. in de aquakultuur. Ph. D. thesis, State University of Ghent

Sorgeloos, P., Lavens, P., Léger, Ph., Tackaert, W., Versichele, D. (1985). Manual for the culture and use of brine shrimp Artemia in aquaculture. Manual prepared for the Belgian Administration for Development Cooperation and the FAO of the United Nations, Artemia Reference Center, Belgium

Tackaert, W., Vanhaecke, P., Aertsen, L., Sorgeloos, P. (1986). Study of the heritability of quantitative characteristics in Artemia through standardized cross-breeding experiments. In: Sorgeloos, P., Bengtson, D. A., Decleir, W. (ed.) Proceedings Second International Symposium on the brine shrimp Artemia. Universa Press, Wetteren, Belgium. (In press)

Thun, A. M., Starret, G. L. (1986). The effect of cold, hydrated dormancy and salinity on the hatching of Artemia cysts from Mono Lake, Califormia, USA. In: Sorgeloos, P. Bengtson, D. A., Decleir, W (ed.) Proceedings Second International Symposium on the brine shrimp Artemia. Universa Press, Wetteren, Belgium. (In press) 
Van Der Linden, A., Blust, R., Doumen, C. (1986). An action spectrum for light-induced hatching of Artemia cysts. In: Sorgeloos, P., Bengtson, D. A., Decleir, W. (ed.) Proceedings Second International Symposium on the brine shrimp Artemia. Universa Press, Wetteren, Belgium. (In press) Vanhaecke, P., Sorgeloos, P. (1982). International Study on Artemia. XVIII. The hatching rate of Artemia cysts - a comparative study. Aquacultural Eng. 1 (4): 263-273
Vanhaecke, P., Sorgeloos, P. (1983). International Study on Artemia. XIX. Hatching data for ten commercial sources of brine shrimp cysts and re-evaluation of the hatching efficiency concept. Aquaculture 30: 43-52

Voronov, P. M. (1973). Observations on reproduction of Artemia salina in water bodies of Crimea. Zool. Zh. 52 (6): 945-947

This article was submitted to the editor; it was accepted for printing on April 17, 1986 